\title{
Orchid (Orchidaceae) decline in the Catoctin Mountains, Frederick County, Maryland as documented by a long-term dataset
}

\author{
Wesley M. Knapp • Richard Wiegand
}

Received: 16 December 2013/Revised: 25 March 2014/ Accepted: 12 April 2014/

Published online: 1 May 2014

(C) The Author(s) 2014. This article is published with open access at Springerlink.com

\begin{abstract}
A 41-year study (1968-2008) of the orchids of the Catoctin Mountains, Frederick County, Maryland reveals that 19 of 21 species have experienced precipitous declines. Four of these species are currently considered Threatened or Endangered by the State of Maryland and another two are considered Rare. Annual census data at 167 sites from throughout the Catoctin Mountains on protected and unprotected lands (private and public) show a loss of three species from the study area, a decline of $>90 \%$ (ranging from 99 to $91 \%$ ) in seven species, and a decline of $<90 \%$ (ranging from 51 to $87 \%$ ) for nine species. Each species was analyzed using Ordinary Least Squares Analysis to show trends and document corresponding $\mathrm{R}^{2}$ and $\mathrm{p}$ values. We tested the hypothesis that this decline is due to intensified herbivory by white-tailed deer. The overall orchid census data is significantly inversely-correlated $(\mathrm{R}=-0.93)$ to the white-tailed deer harvest data of Frederick County (a surrogate for population size), which includes the entirety of the study area. Platanthera ciliaris showed a huge expansion at a single site explicitly managed for this species otherwise this orchid showed a decline similar to the other species. Proper management is critical for the continuation of the orchid species in this study, be it control of the white-tailed deer herd or combating woody plant succession in the case of $P$. ciliaris.
\end{abstract}

Keywords Deer herbivory $\cdot$ Habitat management $\cdot$ Rare species $\cdot$ Conservation

Communicated by Danna J. Leaman.

W. M. Knapp (凹)

Maryland Department of Natural Resources, Wildlife and Heritage Service, PO Box 68, Wye Mills, MD 21679, USA

e-mail:wknapp@dnr.state.md.us

R. Wiegand

Maryland Department of Natural Resources, Wildlife and Heritage Service, 8831 Eureka Lane,

Walkersville, MD 21793, USA 


\section{Introduction}

Of all the land plants the orchids (Orchidaceae) are among the most beautiful and charismatic. Found on all continents except Antarctica, the Orchidaceae is one of the most diverse families of flowering plants with approximately 20,000 species (Smith et al. Smith 2004). In Maryland, 21 genera and 51 species are known (Knapp and Naczi unpublished data) occupying a diverse array of habitats from dry to wet substrates in forested to opensunny conditions (Brown and Brown 1984). In the Catoctin Mountains of Frederick Co., Maryland, 27 species (native and non-native) have been informally reported (Wieg and unpublished data). Of these 27 species, 21 were readily occurring at the onset of this study. Four are listed as threatened or endangered (Maryland Natural Heritage Program 2010): longbract frog orchid (Coeloglossum viride var. virescens, yellow fringed orchid (Platanthera ciliaris), greater purple fringed orchid (Platanthera grandiflora), and yellow nodding ladie's tresses (Spiranthes ochroleuca). Two are listed as rare (Maryland Natural Heritage Program 2010): brown widelip orchid (Liparis liliifolia), and palegreen orchid (Platanthera flava var. herbiola).

The understanding of how species respond to natural or management-induced habitat changes is a prerequisite for successful species conservation (Hegland et al. 2001). Species populations are known to be highly variable over a short time scale due to many environmental conditions (e.g., competition, climate). Therefore, long-term population data are needed to obtain reliable information on the life history and population dynamics of any species (Waite and Hutchings 1991; Fieberg and Ellner 2001). Many long-term studies of various terrestrial orchid groups show natural population fluctuations or effects of temporal environmental conditions (Tamm 1972; Hutchings 1987; Mood 1989; Willems and Meiser 1998; Gillman and Dodd 1998; Shefferson et al. 2003; Kery and Gregg 2004; Pfeifer et al. 2006).

The effects of white-tailed deer (Odocoileus virginianus Boddaert) herbivory on vegetation and plant community structure is well known (Augustine and Frelich 1998; Gill and Beardall 2001; Rooney 2001; Russell et al. 2001; Horsley et al. 2003, Rooney and Waller 2003; Côté et al. 2004; Krueger and Peterson 2006; Mudrak et al. 2009; Freker et al. 2013). Overtime, elevated levels of herbivory can lead to density decline and extirpation of herbivory intolerant plants (Rooney and Dress 1997a; Fletcher et al. 2001). Regionally, a number of studies have shown impacts of herbivory on various species (Whigham 1990; Whigham and O'Neill 1991; Rooney and Dress 1997b; McGraw and Furedi 2005). Numerous studies have shown browsing by white-tailed deer at densities greater than 15-20 deer/mi ${ }^{2}$ can influence forest regeneration success (Hough 1965; Behrend et al. Behrend 1970; Marquis 1981; Tilghman 1989). Langdon (1985) noted that deer impacts on plant communities consists of three primary effects: (1) failure of plants to reproduce, (2) alteration of species composition which occurs when deer remove preferred browse species and indirectly create opportunities for less preferred or unpalatable species to proliferate, and (3) extirpation of highly palatable plants, especially those that were naturally uncommon or of local occurrence.

During the course of this study the deer population of the Catoctin Mountains became sizeable and an obvious 'browse line' developed (National Park Service 2008). Porter (1991) estimated the deer density at Catoctin Mountain Park, located within the study area, to exceed $40 \mathrm{deer} / \mathrm{km}^{2}$ (100 deer $\left./ \mathrm{mi}^{2}\right)$ and research has established that such high deer densities have negative impacts on plant and animal species (Anderson 1994; Alverson et al. 1998; Augustine and Frelich 1998; de Calesta 1994; McShea and Rappole 2000). 
The initial intent of this long-term study was to document changes to orchid demographics in a large area over time. The unanticipated declines documented stimulated an investigation into possible causes. This post-facto effort links the declines of orchids to the deer population, using deer harvest data as a surrogate for population. The objectives of this study are to raise awareness of the decline in orchid species in the Catoctin Mountains and show the main cause of this decline is most likely herbivory by white-tailed deer.

\section{Study area}

The Catoctin Mountains study area is approximately $485 \mathrm{~km}^{2}\left(301 \mathrm{mi}^{2}\right)$. Located in Frederick Co., Maryland and comprises the easternmost ridge of the Blue Ridge Mountains (Fig. 1; Schmidt 1993). The Catoctin Mountains are oriented in a northeast/southwest direction and stretch approximately $80 \mathrm{~km}$ from their origin at South Mountain near Emmitsburg, MD, to the south just past Leesburg, VA, where they become undifferentiated into the Piedmont Physiographic Province (Schmidt 1993). The point of greatest elevation is just southwest of Cunningham Falls State Park at $538 \mathrm{~m}(1,765 \mathrm{ft})$. The Catoctin Mountains are located in the transition between two of Köppen's climatic types; the Cfa, of Humid Subtropical climates, and Dfa, of Humid Continental climates (Markus et al. 2006). Average weather conditions at Catoctin Mountain Park, located near Thurmont, MD, indicate that the climate is cool-temperate with a mean annual temperature of $12.0{ }^{\circ} \mathrm{C}$ $\left(53.6^{\circ} \mathrm{F}\right)$ and a mean annual precipitation of $115.2 \mathrm{~cm}$ (45.3) in (NOAA 2013).

Floristically, the Catoctin Mountains are dominated by deciduous forests comprised primarily of oak (Quercus L. spp.). NatureServe (2011) documents six forested systems present within the study area: Appalachian Hemlock (Tsuga Canadensis (L.))-Northern Hardwood Forest, Central Appalachian dry oak-pine (Pinus L. spp.) forests, Central Appalachian pine-oak rocky woodlands, central Appalachian steam and riparian forests, North-Central Appalachian acidic cliff and talus, and northeastern interior dry-mesic oak forests.

The study area is located within the Catoctin-South Mountain Region of the Blue Ridge and is underlain by Catoctin metabasalt greenstone (Schmidt 1993; Reger and Cleaves 2008). The area contains a number of large protected lands including Catoctin Mountain Park, Cunningham Falls State Park, Frederick Municipal Forest, Gambrill State Park, and Camp David, the Presidential retreat. Culling of the deer herd was not allowed on Catoctin Mountain Park until 2010 (Loncosky personal communication).

\section{Materials and methods}

Twenty-one species of orchids were inventoried annually at 167 sites, during various times of year beginning in 1968 and ending in 2008 using traditional Natural Heritage Program inventory methods, namely the Observational Data Standard (Fig. 1; NatureServe 2006). The surveys were conducted by the second author or, occasionally, with assistance of other knowledgeable individuals. This reduced the likelihood that a site would not be thoroughly explored and helped limit issues with varying survey efforts among distinct surveyors over the years of the survey. Each site was thoroughly explored during surveys to ensure an accurate census. Individuals were counted using a hand held tally counter with the results of each site census recorded in a field notebook. The detailed locations of these sites are mapped and available upon request. They are not included here because a number of these 


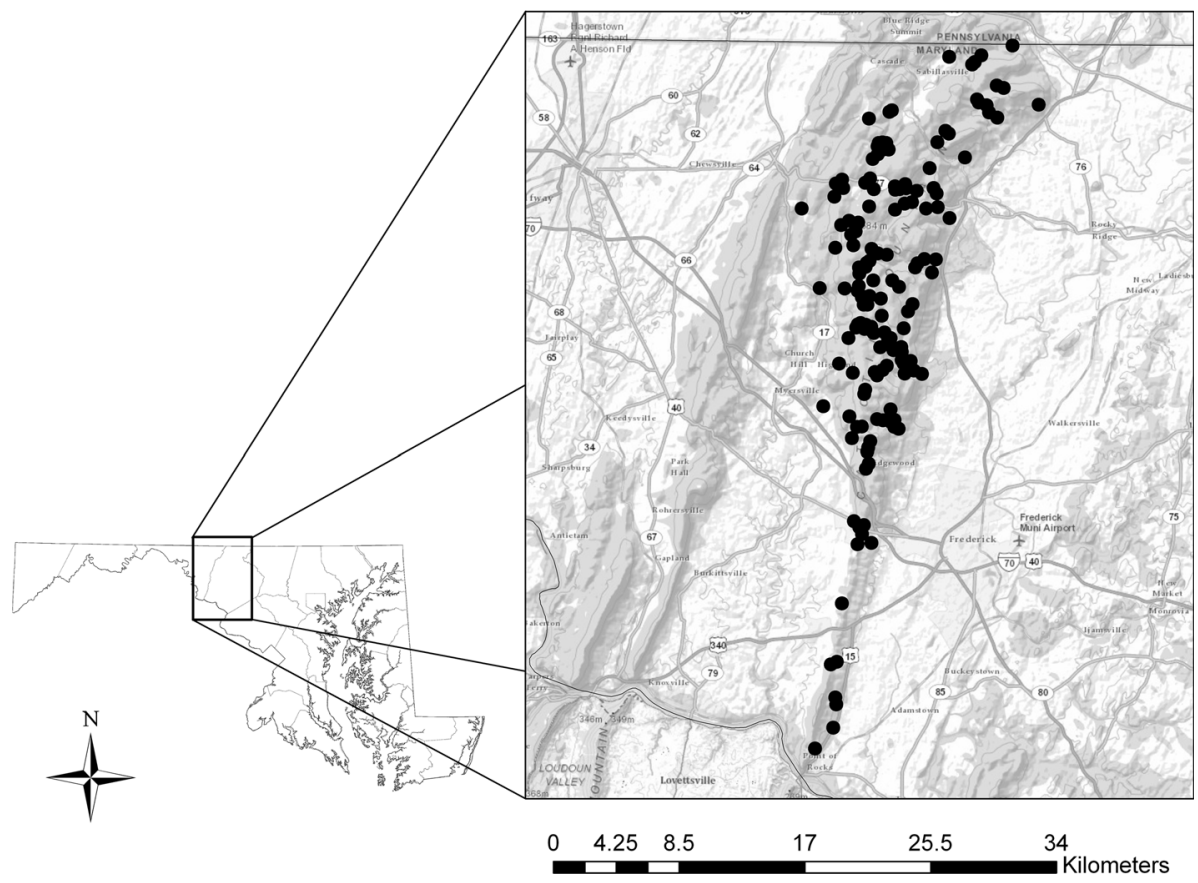

Fig. 1 Map of the Catoctin Mountains study area with State of Maryland depicted to the left. Circles locations of a survey site

species are considered by the Maryland Natural Heritage Program to be vulnerable to collecting. The study sites are located throughout the Catoctin Mountains and stretch nearly $50 \mathrm{~km}(31 \mathrm{mi})$ north to south and $16 \mathrm{~km}(10 \mathrm{mi})$ east to west (Fig. 1). The majority of these sites (142) are located in the northern portion of the Catoctin Mountains, where the Mountains become wider and occupy more landmass. Numerous sites have more than one species of orchid that are not easily detected at the same time of year due to distinct flowering and fruiting periods between species. This required several site visits throughout the year to accurately census the orchids at a given site. The total number of years that each individual species was censused varied (Table 1) as species were encountered at different times during the study and not all species were sampled each year.

Because species were not sampled each year, missing data were estimated using the regression substitution method (Kauffman et al. 2003; Little and Rubin 1987). This method calculates a value for the missing variable by calculating a trend from each species at an individual site. To prevent simply reinforcing the trend line from which the missing variable is calculated some error is added (Little and Rubin 1987; SPSS 2004).

After a complete dataset was constructed, data for each species were summarized by years of inventory, total number of years, number of sites, highest census number with year, final census number, actual percent decline (calculated using highest census versus final census), and percent of data missing per species. These types of data (year and census) lend themselves to trend analysis using ordinary least squared analysis (Gotelli and Ellison 2004). These analyses were conducted using Systat version 11 (SPSS 2004). Each species was graphed showing total census on the $\mathrm{Y}$-axis and year on the $\mathrm{X}$-axis. The corresponding best fit line, $\mathrm{R}^{2}$ value and $\mathrm{p}$-value were calculated. 
Table 1 Orchid summary statistics

\begin{tabular}{|c|c|c|c|c|c|c|c|}
\hline Species & $\begin{array}{l}\text { Years of } \\
\text { inventory }\end{array}$ & $\begin{array}{l}\text { Total } \\
\text { years }\end{array}$ & $\begin{array}{l}\text { No. } \\
\text { of } \\
\text { sites }\end{array}$ & $\begin{array}{l}\text { Highest } \\
\text { census } \\
\text { (year) }\end{array}$ & $\begin{array}{l}\text { Final } \\
\text { census } \\
(2008)\end{array}$ & $\begin{array}{l}\text { Actual } \\
\% \\
\text { census } \\
\text { decline }\end{array}$ & $\begin{array}{l}\% \text { Data } \\
\text { missing }\end{array}$ \\
\hline Aplectrum hyemale & 1968-2008 & 41 & 6 & $151(1973)$ & 4 & 97.35 & 2.4 \\
\hline $\begin{array}{l}\text { Coeloglossum viride var. } \\
\text { virescens }\end{array}$ & 1983-2008 & 26 & 6 & $117(1986)$ & 38 & 66.96 & 3.8 \\
\hline $\begin{array}{l}\text { Corallorhiza maculata var. } \\
\text { maculata }\end{array}$ & 1982-2008 & 27 & 5 & $126(1982)$ & 5 & 96.06 & 1.5 \\
\hline C. odontorhiza var. odontorhiza & 1981-2008 & 28 & 13 & 977 (1986) & 100 & 92.55 & 3.8 \\
\hline Cypripedium acaule & 1984-2008 & 25 & 25 & $1200(1984)$ & 160 & 86.3 & 5.9 \\
\hline C. parviflorum var. pubescens & 1981-2008 & 28 & 17 & 127 (1982) & 0 & 100 & 4.4 \\
\hline Epipactis helleborine & 1987-2008 & 22 & 8 & $392(1993)$ & 15 & 96.17 & 1.5 \\
\hline Galearis spectabilis & 1981-2008 & 28 & 21 & 1319 (1985) & 257 & 80.52 & 5.3 \\
\hline Goodyera pubescens & 1983-2008 & 26 & 22 & 761 (1984) & 115 & 84.38 & 6.4 \\
\hline Isotria verticillata & 1982-2008 & 27 & 14 & $966(1985)$ & 110 & 87.23 & 4.5 \\
\hline Liparis liliifolia & 1980-2008 & 29 & 11 & $269(1983)$ & 27 & 91.15 & 1.9 \\
\hline Platanthera ciliaris $^{\mathrm{a}}$ & 1974-2008 & 35 & 10 & 299 (1974) & 50 & 81.62 & 0.6 \\
\hline P. clavellata & 1980-2008 & 29 & 23 & $1518(1981)$ & 517 & 61 & 1.6 \\
\hline P. flava var. herbiola & 1985-2008 & 26 & 7 & $286(1987)$ & 270 & 5.59 & 1.2 \\
\hline P. grandiflora & 1979-2008 & 30 & 12 & $476(1983)$ & 233 & 51.05 & 2.2 \\
\hline P. lacera & 1980-2008 & 29 & 9 & $230(1980)$ & 55 & 76.09 & 0.4 \\
\hline P. orbiculata & 1983-2008 & 26 & 9 & 59 (1984) & 0 & 100 & 2.1 \\
\hline Spiranthes cernua & 1984-2008 & 25 & 10 & $244(1984)$ & 31 & 87.3 & 0 \\
\hline S. lacera var. gracilis & 1981-2008 & 28 & 8 & $223(1983)$ & 2 & 99.15 & 1.8 \\
\hline S. ochroleuca & 1985-2008 & 24 & 4 & $41(1986)$ & 0 & 100 & 0 \\
\hline Tipularia discolor & 1978-2008 & 31 & 3 & $62(1980)$ & 5 & 91.94 & 0 \\
\hline
\end{tabular}

Nomenclature for the orchid species follows USDA Plants (2013)

a The data presented for $P$. ciliaris excludes the single site actively managed for this species

No white-tailed deer population estimates are available for Frederick County or the Catoctin Mountains. White-tailed deer harvest data is available for Frederick County. These data were acquired from Brian Eyler (Wildlife and Heritage Service Deer Project Leader-Maryland Department of Natural Resources) and were used to provide an index of deer population size (Roseberry and Woolf 1991).

An inverse correlation analysis comparing the overall orchid census from 1987 to 2008 to the annual Frederick County white-tailed deer harvest during the same time period was completed. The year 1987 was selected for this analysis because this is the first year a complete dataset is available for all 21 species of orchids surveyed during the study.

\section{Results}

Nineteen species had significant declines, three species disappeared, one species was stable across the study and one expanded. Data is presented in three arbitrarily assigned categories for ease of presentation: species that disappeared, species with $>90 \%$ decline, and 
species with $<90 \%$ decline. Seven species showed a total decline of over $90 \%$ (Table 1; Fig. 2), and nine showed declines from 51 to $87 \%$ (Table 1; Fig. 3). Platanthera flava var. herbiola, did not decline, and $P$. ciliaris experienced significant growth (Table 1; Fig. 3 ). The $\mathrm{R}^{2}$ values are presented on each species census graphs (Figs. 2, 3). All regressions had calculated p-values of $<0.005$.

Species that disappeared

Three species disappeared during the study period with census totals becoming zero (Table 1; Fig. 2). These were the greater yellow lady's slipper (Cypripedium parviflorum var. pubescens), lesser round-leaved orchid (Platanthera orbiculata) and Spiranthes ochroleuca. The number of sites for $P$. orbiculata and $S$. ochroleuca ( 9 and 4 , respectively), years of survey (26 and 24), and initial number of individuals (59 and 41) are very similar. The loss of $C$. parviflorum var. pubescens is more striking as over 28 years there were more sites (17) and a larger number of individuals (127).

Species with $>90 \%$ decline

Seven species showed a total decline of $>90 \%$ (Table 1; Fig. 2). Among these species is the only non-native species of orchid known in the Catoctin Mountains, broadleaf helleborine (Epipactis helleborine). The six other species are Adam and Eve orchid (Aplectrum hyemale), summer coralroot (Corallorhiza maculata var. maculata), autumn coralroot (Corallorhiza odontorhiza var. odontorhiza), Liparis liliifolia, northern slender lady's
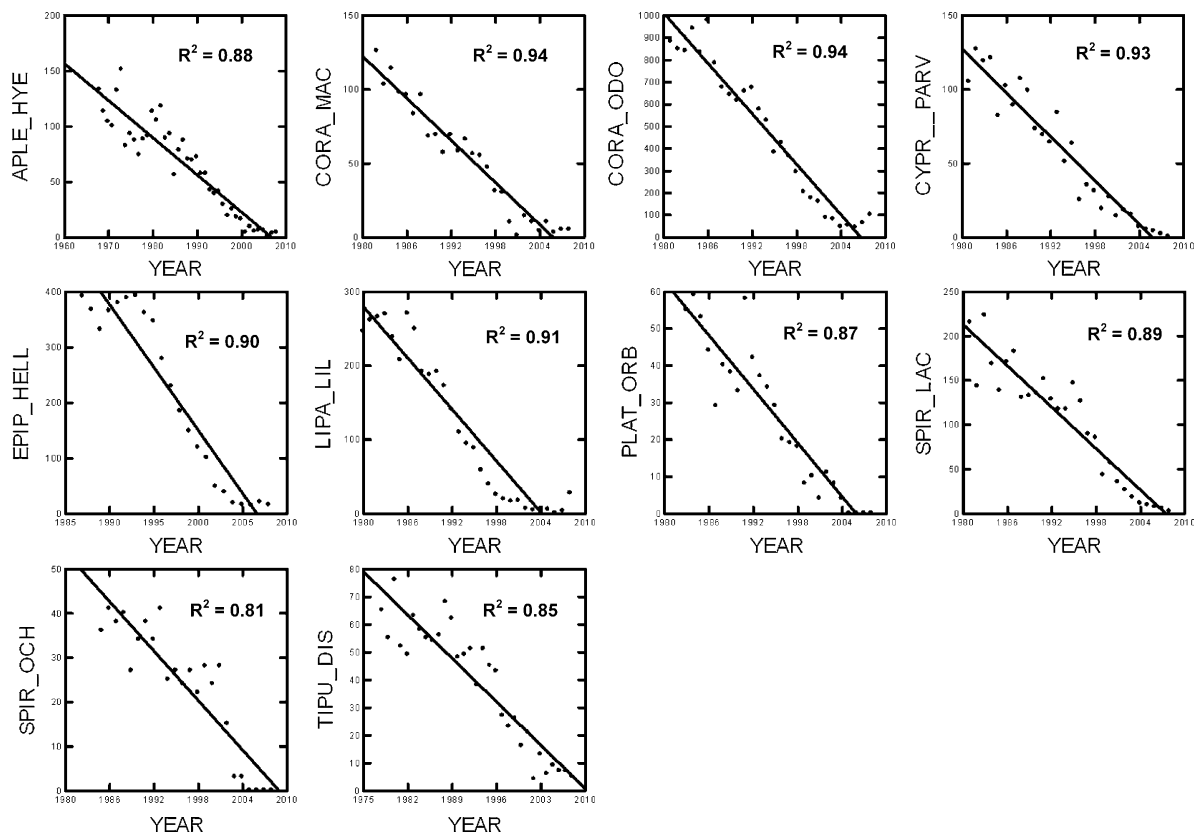

Fig. 2 Species with a $>90 \%$ total decline, including the 'species that disappeared'. Census $(Y$-axis $)$, year (X-axis) with name for each species abbreviated along the Y-axis. Top row: A. hyemale, C. maculata var. maculata, C. odontorhiza var. odontorhiza, C. parviflorum var. pubescens. Middle row: E. helleborine, L. liliifolia, P. orbiculata, S. lacera var. gracilis. Bottom row: S. ochroleuca, T. discolor 

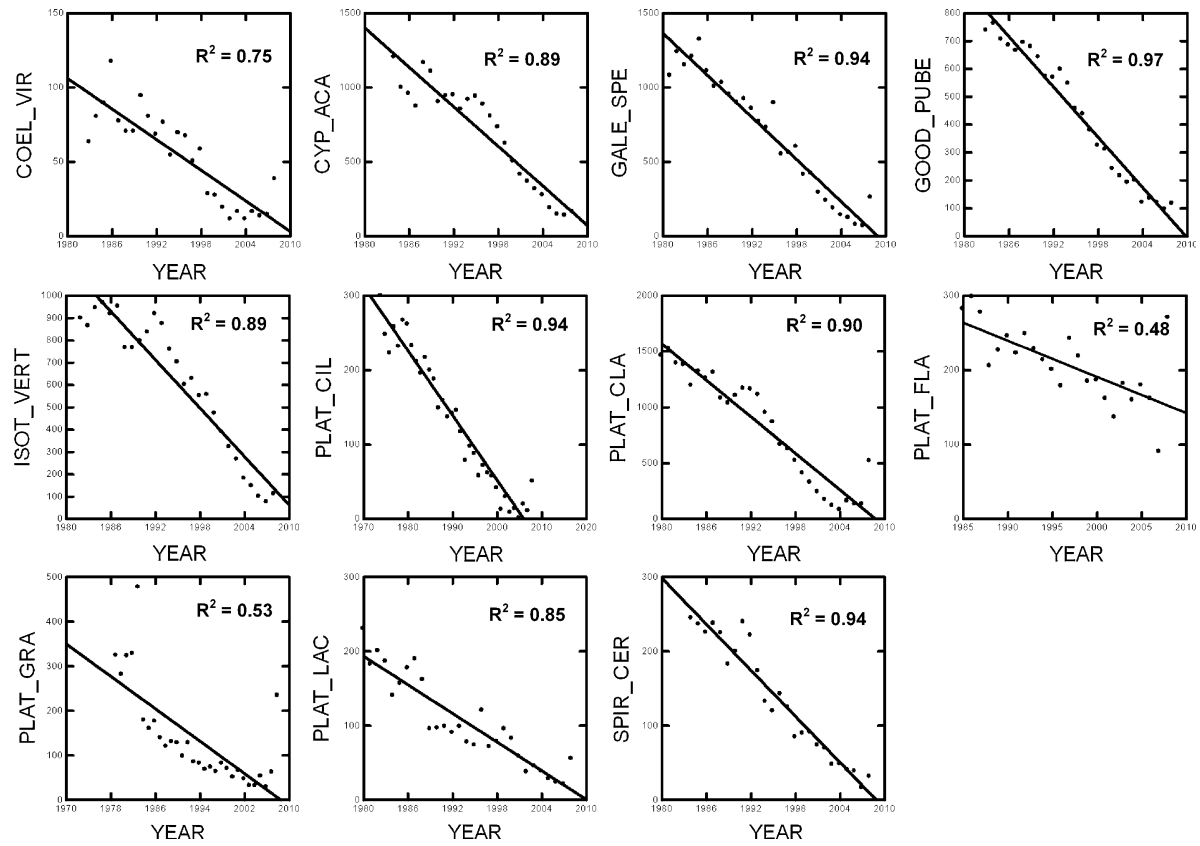

YEAR

Fig. 3 Species with a $<90 \%$ total decline. Census ( $Y$-axis), year $(X$-axis) with name for each species abbreviated along the $Y$-axis. Top row: $C$. viride var. virescens, $C$. acaule, G. spectabilis, G. pubescens. Middle row: I. verticillata, $P$. ciliaris, $P$. clavellata, $P$. flava var. herbiola. Bottom row: $P$. grandiflora, $P$. lacera, S. cernua

tresses (Spiranthes lacera var. gracilis), and the crippled crainfly (Tipularia discolor). Liparis liliifolia showed an increase in 2008 (Fig. 2). After averaging only 4 plants/year census from 2002 to 2007,27 plants were found in 2008. Of these species the decline of $C$. odontorhiza is the most striking with a census high of 977 individuals in 1986 declining to just 70 individuals in 2008. The $\mathrm{R}^{2}$ values for these species are among the highest documented during the study, all of which range from 0.85 to 0.94 (Fig. 2).

Species with a $<90 \%$ decline

Nine species showed declines of $<90 \%$ (Table 1; Fig. 3). These species are Coeloglossum viride var. virescens, moccasin flower (Cypripedium acaule), showy orchid (Galearis spectabilis), downy rattlesnake plantain (Goodyera pubescens), large whorled pogonia (Isotria verticillata), small green wood orchid (Platanthera clavellata), Platanthera grandiflora, green fringed orchid (Platanthera lacera), and nodding lady's tresses (Spiranthes cernua). Cypripedium acaule and $G$. spectabilis are arguably the most common terrestrial orchids in the Catoctin Mountains. These showed declines from 1,168 and 1,319 individuals to 128 and 66 individuals, respectively. Five of these species (C. viride var. virescens, I. verticillata, $P$. clavellata, $P$. grandiflora, and $P$. lacera) showed an obvious yet unexpected census increase in 2008 (Fig. 3). The $\mathrm{R}^{2}$ values for these species are more variable than the $>90 \%$ group. Goodyera pubescens shows the highest $\mathrm{R}^{2}$ value $(0.97)$ of all species in this study. Only $P$. grandiflora $\left(\mathrm{R}^{2}=0.53\right)$ and $C$. viride var. virescens $\left(\mathrm{R}^{2}=0.75\right)$ have $\mathrm{R}^{2}$ values $<0.85$. 
Fig. 4 Inverse correlation of the deer harvest of Frederick County to overall orchid census. Squares no. of deer harvested, Circles individual orchids census

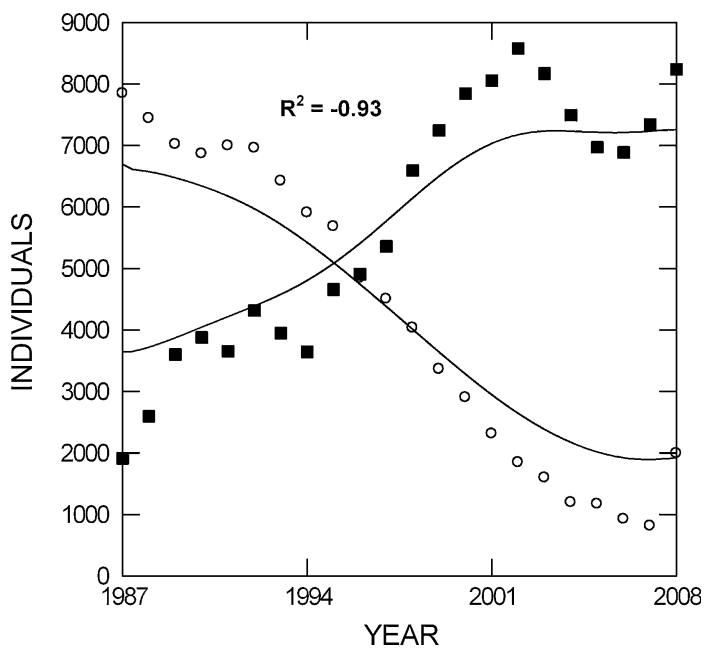

Species that did not decline

Two species did not show declines. These are Platanthera ciliaris and Platanthera flava var. herbiola. Platanthera flava var. herbiola shows a very slight decline (16 plants) but no highly correlated $\mathrm{R}^{2}$ values (Table 1 ; Fig. 3). Platanthera ciliaris shows an overall census increase, but $94.8 \%$ of this growth is found at a single site called Whiskey Springs Pond. If this site is removed from the dataset, the species declines by over $94 \%$ with $\mathrm{R}^{2}=0.94$ (Table 1; Fig. 3). From 1984 to 1988 an average of 14 plants were observed at Whiskey Springs Pond. After the implementation of a periodic mowing regime, beginning in 1989 , the average annual census has increased to 227 plants.

Relationship between orchid census and deer harvests

Though deer harvest data is not a perfect replacement for deer population data, it does illustrate trends. In the 1900's white-tailed deer were nearly extirpated from the State of Maryland (Maryland Department of Natural Resources 2013). In Frederick County, the number of individual deer harvested from 1960 to 1980 increased from 229 to 710, a nearly threefold increase. From 1980 to 2000, the harvest showed exponential growth going from 631 individuals to 7,843 individuals, a 12-fold increase (Fig. 4). From 2001 to 2008 the number of deer harvested became more erratic. The harvest peaks at 8,578 in 2002, decreases to 6,884 in 2006, then increases once again to 8,238 in 2008 (Fig. 4). The Inverse Correlation Analysis comparing the total deer harvest in Frederick County, to the overall orchid census from 1987 to 2008 yielded a $R^{2}$ value of -0.93 (Fig. 4).

\section{Discussion}

Recent studies of long-term orchid population data documented annual fluctuations in orchid species (Alexandersson and Agren 1996, Gillman and Dodd 1998, Pfeifer et al. 2006, Rasmussen and Whigham 1998). The data collected in this study show no such annual fluctuations. This makes an explanation based on weather patterns or natural species 
fluctuations doubtful. Only after compiling these data did the severity and consistency of the trends become evident. Though there are many potential factors that may be contributing to these declines, including invasive species and non-target impacts to native pollinators from chemical spraying for non-native gypsy moth (Lymantria dispar L), insufficient data exist to conduct scientifically meaningful tests.

The impact of white-tailed deer herbivory was an obvious potential cause of this decline and an independent dataset existed to examine this factor. Studies on the impacts of herbivory to understory herbs are numerous and show herbivory represents a significant threat (Whigham 1990; Anderson 1994; Augustine and Frelich 1998; Ruhren and Handel 2000, 2003; Fletcher et al. 2001; Knight 2004). Regionally, deer herbivory is believed to be so intense it may cause the extinction of American ginseng (Panax quinquefolius L.), a now rare herbaceous plant (McGraw and Furedi 2005).

The deer harvest data for Frederick County, shows a significantly high inverse correlation $\left(\mathrm{R}^{2}=-0.93\right)$. The inverse correlation argues that the white-tailed deer population of Frederick County is the most likely cause of this decline. Given the level of urbanization and development in Frederick County, it is expected that the majority of the deer harvested from Frederick County came from within the study area. The public lands in the Catoctin Mountains account for $88 \%$ of all the publicly held lands available for hunting in Frederick County (Maryland Department of Natural Resources 2013). Although deer population density data are not available within the study area, it is reasonable to assume that trends in the study area would mirror county-wide trends.

The increase in orchids in 2008 was unexpected and is likely a response to a decline in the deer population. The deer harvest dropped from nearly 9,000 individuals in 2001 to 7,000 in 2006. Liberalized bag limits are likely the result of the harvest increase in 2007 to 2008 (B. Eyler pers. comm). We expect as the white-tailed deer population continues to decline the response in orchid species will continue to be favorable. Seedlings of many terrestrial species are subterranean and seeds may still be present in the seed bank (Rasmussen and Whigham 1998). Future inventory should be conducted to determine the current orchid census at a subset of these sites given the recent implementation of deer control efforts at Catoctin Mountain Park. Deer exclosure studies should be conducted to further test the hypothesis that deer herbivory is causing this decline and to document overall herbaceous species response. It is likely that other plant groups have seen a very similar decline (i.e. Trillium, Lilium, Carex) but given no dataset exists it can only be inferred from a lack of diversity throughout the study area or a response to deer exclosures.

The lack of overall decline in Platanthera flava var. herbiola is caused by a count of 270 individuals in 2008, up from just 90 in 2007 (Fig. 3). The only species that showed an increase during this study period was $P$. ciliaris. The single site that explains this growth is owned and managed by the State of Maryland. Platanthera ciliaris is a pyrophytic species requiring open conditions such as open woods, roadsides, and seepage slopes (Sheviak 2002). To mimic the disturbance requirements of this rare species, the site has been mowed periodically beginning in 1989 (D. Rohrback pers. com.). Platanthera ciliaris has responded positively to the disturbance regime.

This study shows the value and utility of long-term datasets over a large area. This study also challenges the underlying idea that an area is protected just because it is publicly owned. Proper natural resource management is a prerequisite for species survival. In the case of this study, we were very fortunate to have a long-term dataset showing the declines that occurred. Most areas that support similarly-sized deer populations have no such datasets and damage to the flora will be witnessed but the actual declines of plant species will only be inferred due to a lack of botanical diversity. It is likely that adjacent states with 
similar deer populations, large parks with no easy access for hunters, and lands that do not allow hunting have seen or will see impacts to vegetation similar to these. Without longterm data sets as a point of reference, even catastrophic declines such as the ones published here, may go unnoticed.

Acknowledgments We thank the Maryland Department of Natural Resources, Wildlife and Heritage Service for allowing us time toward this project. We thank the multitude of landowners who allowed access to study sites. We thank the public land managers where these surveys occurred including staff of Catoctin Mountain Park, Cunningham Falls State Park, Frederick Municipal Forest, and Gambrill State Park. A valuable and critical review of this manuscript was provided by D. Whigham. Numerous individuals assisted in this project in various ways or made comments to better this paper including, D. Brinker, G. Brewer, B. Eyler, J. Harrison, R. Loncosky, W. McAvoy, J. McKnight, R. Naczi, D. Rohrback, S. Smith, T. Larney, and G. Therres.

Open Access This article is distributed under the terms of the Creative Commons Attribution License which permits any use, distribution, and reproduction in any medium, provided the original author(s) and the source are credited.

\section{References}

Alexandersson R, Agren J (1996) Population size, pollinator visitation and fruit production in the deceptive orchid Calypso bulbosa. Oecologia 107:533-540

Alverson WS, Waller DM, Solheim SL (1998) Forests too deer: edge effects in northern Wisconsin. Conserv Biol 2:348-358

Anderson DJ (1994) Height of white-flowered trillium (Trillium grandiflorum) as an index of deer browsing intensity. Ecol Appl 4:104-109

Augustine DJ, Frelich LE (1998) Effects of white-tailed deer on populations of an understory forb in fragmented deciduous forests. Conserv Biol 12:995-1004

Behrend DF, Mattfeld GF, Tierson WD, Wiley JE III (1970) Deer density control for comprehensive forest management. J For 68:695-700

Brown RG, Brown ML (1984) Herbaceous plants of Maryland. Port City Press, Baltimore, p 1127

Côté SD, Rooney TP, Tremblay JP, Dussault C, Waller DM (2004) Ecological impacts of deer overabundance. Annu Rev Ecol 35:113-147

de Calesta DS (1994) Effects of white-tailed deer on songbirds within managed forests in Pennsylvania. J Wildl Manag 58:711-718

Fieberg J, Ellner SP (2001) Stochastic matrix models for conservation and management: a comparative review of methods. Ecol Lett 4:244-266

Fletcher JD, Shipley LA, McShea WJ, Shumway DL (2001) Wildlife herbivory and rare plants: the effects of white-tailed deer, rodents, and insects on growth and survival of Turk's cap lily. Biol Conserv 101:229-238

Freker K, Sonnier G, Waller DM (2013) Browsing rates and ratios provide reliable indices of ungulate impacts on forest plant communities. For Ecol Manag 291:55-64

Gill RMA, Beardall V (2001) The impact of deer on woodlands: the effects of browsing and seed dispersal on vegetation structure and composition. Forestry 74:209-218

Gillman MP, Dodd ME (1998) The variability of orchid population size. Bot J Linn Soc 126:65-74

Gotelli N, Ellison A (2004) A primer of ecological statistics. Sinauer Associates, Sunderland, p 510

Hegland SJ, van Leeuwen M, Oostermeijer JGB (2001) Population structure of Salvia pratensis in relation to vegetation and management of Dutch dry floodplain grasslands. J Appl Ecol 38:1277-1289

Horsley SB, Stout SL, de Calesta DS (2003) White-tailed deer impact on the vegetation dynamics of a northern hardwood forest. Ecol Appl 13:98-118

Hough AF (1965) A twenty-year record of Understory vegetation change in a virgin Pennsylvania forest. Ecology 46:370-373

Hutchings MJ (1987) The population biology of the early spider orchid, Ophyrs sphegodes Mill. I. A demographic study from 1975 to 1984. J Ecol 75:711-727

Kauffman MJ, Frick WF, Linthicum J (2003) Estimator of habitat-specific demography and population growth for Peregrine Falcons in California. Ecol Appl 13:1802-1816 
Kery M, Gregg KB (2004) Demographic analysis of dormancy and survival in the terrestrial orchid Cypripedium reginae. J Ecol 92:686-695

Knight TM (2004) The effects of herbivory on pollen limitation on a declining population of Trillium grandiflorum. Ecol Appl 14:915-1928

Krueger LM, Peterson CJ (2006) Effects of white-tailed deer on Tsuga Canadensis regeneration: evidence of microsites as refugia from browsing. Am Midl Nat 156:353-362

Langdon K (1985) White-tailed deer Action Plan. On file at Catoctin Mountain Park, Thurmont. Supplement to Natural Resource Management Plan, Catoctin Mountain Park, Catoctin

Little RJA, Rubin DB (1987) Statistical analysis with missing data. Wiley, New York, p 408

Markus K, Grieser J, Beck C, Rudolf B, Franz R (2006) World Map of the Köppen-Geiger climate classification updated. Meteorologische Zeitschrift 15:259-263

Marquis DA (1981) Effect of Deer Browsing on Timber Production in Allegheny Hardwoods of Northwestern Pennsylvania. Northeastern Forest Experimental Station, U.S. Forest Service, Broomall, p 10

Maryland Department of Natural Resources (2013) Maryland Guide to Hunting and Trapping. Maryland Department of Natural Resources Wildlife and Heritage Service. http://www.eregulations.com/ maryland/hunting/public-hunting-lands. Accessed Dec 2013

Maryland Natural Heritage Program (2010) Rare, threatened and endangered plants of Maryland. Maryland Department of Natural Resources, Wildlife and Heritage Service, Annapolis

McGraw JB, Furedi MA (2005) Deer browsing and population viability of a forest understory plant. Science 307:920-955

McShea WJ, Rappole JH (2000) Managing the abundance and diversity of breeding bird populations through manipulation of deer populations. Conserv Biol 14:1161-1170

Mood (1989) The dynamics of declining populations of an endangered orchid, Isotria medeoloides. Ecology 70:783-786

Mudrak EL, Johnson SE, Waller DM (2009) Forty-seven year changes in vegetation at the Apostle Island: effects of deer on forest understory. Nat Areas J 29:167-176

National Climatic Data Center (NOAA) (2013). http://www.ncdc.noaa.gov/cdo-web. Accessed 18 Dec 2012

National Park Service (2008) Catoctin Mountain Park final white-tailed deer management plan, Frederick and Washington Counties: environmental impact statement. FES 08-58. National Park Service, Denali National Park and Preserve, p. 340

NatureServe (2006) Observational Data Standard. http://www.natureserve.org/prodServices/pdf/Obs_ standard.pdf. Accessed Dec 2013

NatureServe (2011) International ecological classification standard: terrestrial classifications. NatureServe Central Database, Arlington, p 80

Pfeifer M, Widgand K, Heinrich W, Jetschke G (2006) Long-term demographic fluctuations in an orchid species driven by weather: impactions for conservation planning. J Appl Ecol 43:313-324

Porter WF (1991) White-tailed deer in eastern ecosystems: implications for management and research in National Parks. Natural Resources Report NPS/NRSUNY/NRR-91/05, Washington, DC

Rasmussen HN, Whigham DF (1998) The underground phase: a special challenge in studies of terrestrial orchid populations. Bot J Linn Soc 126:49-64

Reger JP, Cleaves ET (2008) Draft physiographic map of Maryland and explanatory text for physiographic map of Maryland. http://www.mgs.md.gov/coastal/maps/physio.html. Accessed April 2012

Rooney TP (2001) Deer impacts on forest ecosystems: a North American perspective. Forestry 74:201-208

Rooney TP, Dress WJ (1997a) Escaping herbivory: refuge effects on the morphology and shoot demography of the clonal forest herb Maianthemum canadense. J Torrey Bot Soc 124:280-285

Rooney TP, Dress WJ (1997b) Species loss over sixty-six years in the ground-layer vegetation of heart's content, an old-growth forest in Pennsylvania, USA. Nat Areas J 17:297-305

Rooney TP, Waller DM (2003) Direct and indirect effects of deer in forest ecosystems. For Ecol Manag 181:165-176

Roseberry JL, Woolf A (1991) A comparative evaluation of techniques for analyzing white-tailed deer harvest data. Wildl Monogr 117:3-59

Ruhren S, Handel SL (2000) Considering herbivory, reproduction, and gender when monitoring plants: a case study of Jack-in-the-pulpit (Arisaema triphyllum). Nat Areas J 20:261-266

Ruhren S, Handel SL (2003) Herbivory constrains survival, reproduction, and mutualisms when restoring nine temperate forest herbs. J Torrey Bot Soc 130:34-42

Russell FL, Zippin DB, Fowler NL (2001) Effects of white-tailed deer (Odocoileus virginianus on plants, plant populations and communities: a review. Am Midl Nat 146:1-26

Schmidt MF (1993) Maryland's geology. Tidewater publications, Centreville, p 164

Shefferson RP, Proper J, Beissinger SR, Simms EL (2003) Life history trade-offs in a rare orchid: the costs of flowering, dormancy and sprouting. Ecology 82:145-156 
Sheviak CJ (2002) Platanthera ciliaris. In: Flora of North America Editorial Committee (ed) Flora of North America North of Mexico, liliales and orchidales, vol 26. Oxford University Press, New York

Smith N, Mori SA, Henderson A, Stevenson DW, Heald SV (2004) Flowering plants of the Neotropics. Princeton University Press, Princeton, p 680

SPSS (2004) Systat 11. SPSS, Chicago

Tamm CO (1972) Survival and flowering of perennial herbs II. The behavior of some orchids on permanent plots. Oikos 23:23-28

Tilghman NG (1989) Impacts of white-tailed deer on forest regeneration in Northwestern Pennsylvania. J Wildl Manag 53:524-532

USDA Plants Database (2013). http://plants.usda.gov/java/. Accessed April 2012

Waite S, Hutchings MJ (1991) The effects of different management regimes on the population dynamics of Ophrys sphegodes: analysis and description using matrix models. In: Wells TCE, Willems JH (eds) Population ecology of terrestrial orchids. SPB Publishing, The Hauge, pp 161-175

Whigham DF (1990) The effects of experimental defoliation of the growth and reproduction of a woodland orchid, Tipularia discolor. Can J Bot 68:1812-1816

Whigham DR, O'Neill J (1991) The dynamics of flowering and fruit production in two eastern North American terrestrial orchids, Tipularis discolor and Liparis lilifolia. In: Willems JH, Wells TCE (eds) Population ecology of terrestrial orchids. SPB Academic Publishing, The Hague, pp 89-101

Willems JH, Meiser C (1998) Population dynamics and life-history of Coeloglossum viride (L.) Hartm., and endangered orchid species in The Netherlands. Bot J Linn Soc 126:83-93 